\title{
Immigration and Ethnic and Racial Inequality in the United States
}

\section{Citation}

Waters, Mary C., and Karl Eschbach. 1995. Immigration and ethnic and racial inequality in the United States. Annual Review of Sociology 21: 419-446.

\section{Published Version}

http://dx.doi.org/10.1146/annurev.so.21.080195.002223

\section{Permanent link}

http://nrs.harvard.edu/urn-3:HUL.InstRepos:3203265

\section{Terms of Use}

This article was downloaded from Harvard University's DASH repository, and is made available under the terms and conditions applicable to Other Posted Material, as set forth at http:// nrs.harvard.edu/urn-3:HUL.InstRepos:dash.current.terms-of-use\#LAA

\section{Share Your Story}

The Harvard community has made this article openly available.

Please share how this access benefits you. Submit a story.

\section{Accessibility}




\title{
IMMIGRATION AND ETHNIC AND RACIAL INEQUALITY IN THE UNITED STATES
}

\author{
Mary C. Waters \\ Department of Sociology, Harvard University, Cambridge, Massachusetts 02138
}

\author{
Karl Eschbach \\ Center for Demography and Ecology, University of Wisconsin, Madison, Wisconsin \\ 53706
}

KEYWORDS: stratification, race and ethnicity, inequality, economic conditions, immigration

\begin{abstract}
•
This review examines research about current levels and recent changes in ethnic and racial stratification in the United States. Research about ethnic inequality emphasizes that economic stagnation and restructuring are troubling impediments to progress toward equality, and it shows evidence that employers may still use racial and ethnic queues in hiring. A number of issues arise with respect to the incorporation of the new waves of immigrants who have arrived since immigration law reform in 1965. We discuss patterns of adaptation of new immigrants, including available evidence on the ethnic enclave economy and substitution in the labor market of immigrants for native minorities. We summarize new theories and hypotheses about the fate of the children of recent immigrants, and we point to topics in this area needing further research.
\end{abstract}

The half century since the close of World War II has seen numerous changes to the face of racial and ethnic inequality in the United States, while the problem of inequality has endured. When Myrdal published An American Dilemma (1944), the segregationism tolerated by Plessy v. Ferguson was the law of the land, and caste-like barriers separated blacks from whites. Myrdal's chief task was to comprehend the vicious circle that perpetuated these rigid distinctions between the races. By contrast, when Warner \& Srole (1945) described the ethnic 
structure of a representative American city, they described the patterned relationships among its various European national descent groups. The variable these authors used to explain the unequal standing of these groups was the relative lapse of time since each group had migrated to the United States-time for initial distinctions among European descent populations to be erased through homogenization of the social positions of members of different groups.

In the intervening five decades, ascriptive inequality has been transformed by several interrelated events. The economic growth of the postwar decades formed the backdrop for a period of both legal and substantive changes in racial and ethnic inequality in the United States. The formal disabilities of Jim Crow separatism were dismantled by court decisions and by legislative action. Differences between blacks and whites on education and income narrowed. These changes, together with rising general levels of prosperity, created for the first time a substantial black middle class. At the same time, the open opportunity structure created by the expanding economy eased the incorporation of the children and grandchildren of members of the waves of migrants who had flooded to the United States from Europe before and during the early decades of the century.

Yet the story of changing inequality is not a Pollyanna-ish tale. At the close of the twentieth century, group differences have changed shape rather than disappeared. The background of these changes is the changed economic position of the United States. The rapid pace of economic growth in the immediate postwar period could not be sustained after the 1960s, stalling further progress toward racial equality. The export of manufacturing employment has put particular pressure on workers at the lower end of the education distribution where members of racial minority groups are overrepresented. An era of diminished expectations has thrown into relief the continuing relevance of race to economic opportunity.

The new global order has changed the racial and ethnic map of the United States one further way. Immigration has had a very large impact on American society since the 1960s, and most especially it has increased the diversity of the nonwhite population of the United States. In $19907.9 \%$ of the US population was foreign born. The 19.8 million foreign-born people in the United States is the largest number in US history. The sources of immigration flows have also shifted as a consequence of changes in immigration law and in the international pattern of migration flows. In 1990, 25.2\% of the foreign-born population was Asian, $42.5 \%$ Latin American, $22 \%$ European, and $10.3 \%$ from other countries. The decade of the 1980 s produced a large number of immigrants; $44 \%$ of the total 1990 foreign-born population arrived in that decade (Bureau of Census 1993).

In this paper, we review recent literature assessing the impact of three factors-economic restructuring, racial discrimination, and immigration-on 
the current patterns of racial inequality in the United States. Because of the enormous impact of immigration on the composition of America's nonwhite populations, we stress the importance of combining analyses of the economy and of racial and ethnic discrimination, along with the new evidence we have about immigrant absorption and change.

\section{RACIAL AND ETHNIC CATEGORIES}

Scholars who study ethnicity are in general agreement that racial and ethnic categories are social constructions rather than natural entities that are simply "out there" in the world. This constructed character of ethnic groups has several implications for research. One is that the categories the analyst uses are bound to be arbitrary. For example, Office of Management and Budget (OMB) Directive 15 specifies whites, blacks, Hispanics, Native Americans, Asians, and Pacific Islanders as racial and ethnic categories for purposes of enforcement of civil rights legislation. In fact, this is an arbitrary classification scheme which may owe its high level of recognition to Directive 15 itself. Each aggregation includes subpopulations that are themselves diverse, both in the social and cultural organization of sending countries and in the average experiences of group members in the United States. For example the term "Asian" covers the experiences of so-called "model minorities" like the Japanese and Koreans who have high socioeconomic standing in the United States, as well as Southeast Asian populations that have experienced more difficulties.

There are no easy methodological solutions to this problem of classification, except for the recognition of the arbitrariness of any set of ethnic categories. We concentrate on the OMB minority groups in this paper-paying close attention to the distinct subpopulations that make up each aggregation. We do not survey the important literature on white ethnic group inequality because of space limitations. (For a good overview, see Alba 1990, Lieberson 1980, Lieberson \& Waters 1988, Hirschman 1983.)

For most racial and ethnic populations in the United States, classification problems also arise because of the progress of amalgamation and assimilation. The significant exception remains African Americans. Because of the rigidity of the boundary between blacks and whites, few definitional problems arise: rates of intermarriage between blacks and others have historically been low. Even with recent increases, in 1983-86, only 5\% of African American males had marriages involving white spouses, and $2 \%$ of African American females had white spouses (Kalmijn 1993). Further, the common use in the United States of the rule of hypodescent (the one-drop rule) to classify persons of remote black African descent as African American reduces ambiguity about the boundaries of this population (Davis 1991). 
At the other extreme, white ancestry groups have experienced extremely high rates of intermarriage with one another, so that many members of the conventional European national descent populations are of mixed ethnic descent. Scholars have debated whether the patterns of intermarriage and ambiguity about identity among white ethnics mean that assimilation theory accurately portrays the fate of the European descent ethnicities (Greeley 1974, Gans 1979, Alba 1990).

Intermarriage may be especially important in the future evolution of ethnic categories that are neither European nor African. As we discuss in this review, current conditions of incorporation may sustain the structural segregation and the social significance of ethnic descent for these other groups that on average are much greater than for European Americans, but much less than for African Americans.

American Indians, for example, remain the most disadvantaged of major American ethnic categories on census measures of poverty and educational attainment. The persistence of the social significance of a Native American ethnic category 500 years after Columbus's voyage is evidence that ethnic distinctions may in some cases be durable. Yet one of the mechanisms that has sustained the distinctiveness of American Indian communities has been the spinoff of many migrants from these communities into the general American population. Because of the subsequent amalgamation and assimilation of many of these off-reservation migrants and their descendants, far more of the descendants of the inhabitants of North America self-identify as whites rather than as American Indians (Snipp 1989, Eschbach 1995). Thus the assimilation process walks hand in hand with the maintenance of ethnic boundaries.

New immigrant populations from Asia and Latin America may well experience processes of incorporation into the United States that will create considerable confusion about who is a member of a given ethnic population. Data from 1990 showed that because of intermarriage "about one quarter of the 2 million children with at least one Asian parent, and of the 5.4 million with at least one Hispanic parent live in inter-racial households with a white parent or step parent" (Harrison \& Bennett 1995: 40). These percentages will be likely to increase in subsequent generations of descendants. Available evidence suggests that Americans do not consistently use the rule of hypodescent to classify persons of part-Hispanic or part-Asian descent with the 'minority' component of their descent (Davis 1991); ethnic self-identification is inconsistent in these mixed descent populations (Harrison \& Bennett 1995).

These facts suggest the need for considerable caution in making comparisons of different racial and ethnic populations. At any given cross section, different immigrant-ethnic populations will be at different stages of incorporation into the United States population and will be different in the degree to which they are composed of ethnically mixed stock. Differences in the process of amal- 
gamation and subsequently in the formation of ethnic identity may form an important component of the explanation of the size and socioeconomic composition of different groups (Hout \& Goldstein 1994). The social scientific analyst of patterns of ethnic inequality is ill-advised to overlook the transitory quality of the most basic ethnic categories.

\section{BASIC DATA ON INEQUALITY}

With this caveat in mind, Table 1 provides information, based on data from the 1990 census, on median family income, labor force participation, and poverty rates for the major minority groups and whites in the United States. These data show the continuing inequality among American minority groups, when compared with whites. Of the major racial/ethnic minorities in the United States, only Asians have a higher median family income than do whites, with an income of $\$ 41,583$, compared to $\$ 37,630$ for non-Hispanic whites. Amer-

Table 1 Selected socioeconomic indicators for groups in the United States, 1990.

\begin{tabular}{|c|c|c|c|}
\hline Ethnic racial groups & $\begin{array}{c}\text { Median } \\
\text { family } \\
\text { income, } 1989\end{array}$ & $\begin{array}{c}\text { Percentage } \\
\text { persons in } \\
\text { poverty }\end{array}$ & $\begin{array}{c}\text { Labor } \\
\text { force parti- } \\
\text { cipation }^{\mathrm{a}}(\%)\end{array}$ \\
\hline White not Hispanic & $\$ 37,630$ & 10 & 65 \\
\hline Black & 22,430 & 29.5 & 63 \\
\hline American Indian ${ }^{\mathrm{b}}$ & 21,750 & 30.9 & 66.1 \\
\hline Hispanic & 25,064 & 25.3 & 67.5 \\
\hline Mexican & 24,119 & 26.3 & 68.3 \\
\hline Puerto Rican & 21,941 & 31.7 & 60.4 \\
\hline Cuban & 32,417 & 14.6 & 65.0 \\
\hline Asian & 41,583 & 14.0 & 67.4 \\
\hline Japanese & 51,550 & 7.0 & 64.5 \\
\hline Chinese & 41,316 & 14 & 65.9 \\
\hline Filipino & 46,698 & 6.4 & 75.4 \\
\hline Korean & 33,909 & 13.7 & 63.3 \\
\hline Asian Indian & 49,309 & 9.7 & 72.3 \\
\hline Vietnamese & 30,550 & 25.7 & 64.5 \\
\hline Cambodian & 18,126 & 42.6 & 46.5 \\
\hline Hmong & 14,327 & 63.6 & 29.3 \\
\hline Laotian & 23,101 & 34.7 & 58.0 \\
\hline
\end{tabular}

\footnotetext{
${ }^{\text {a }}$ Persons 16 years and over in labor force.

'Includes Eskimos and Aleuts.

Source: U.S. Census of Population, 1990, Social and Economic Characteristics CP-2-1, Washington, DC, U.S. Government Printing Office, 1993.
} 
ican Indians have the lowest median income with $\$ 21,750$, followed closely by blacks and Hispanics. Data on unemployment follow this general pattern, with blacks and American Indians the worst off, followed by Hispanics. Asians have unemployment rates comparable to whites. Poverty rates also follow this general pattern, with blacks showing a poverty rate for individuals that is three times the rate for whites.

\section{Measurement Issues}

These simple rankings mask a more complex picture. The most important variables used to decompose these overall patterns are subethnic groups, gender, and family and household composition. Panethnic groupings such as black, Hispanic, and Asian mask very important differences among subgroups, which we explore further in this review.

There are also important gender differences in relative success of members of these groups-in general, women from minority groups look better in comparison to white women than do minority men compared with white men. So too, family structure is an important variable affecting the levels of success or poverty that a group experiences. For instance, while rates of unemployment and income are much less favorable for blacks and Puerto Ricans than for whites, some of those differences lessen when only husband-wife families are compared across the groups; but because blacks and Puerto Ricans have more families headed by single females, they have lower overall income and success rates. Asians tend to have households with more workers in them than whites; thus when household and family incomes are compared, Asians look better off than when per capita income is compared.

Because of the differences in overall demographics of the groups, as well as differences in the levels of education and other human capital that groups have because of differential migration or the legacy of past inequality and discrimination, sociologists and economists interested in understanding the causes and consequences of racial/ethnic inequality also look at the net returns to human capital for different groups. Using statistical controls, they ask whether a given person with the same background characteristics, such as level of education, region of residence, gender, marital characteristics, has the same earnings as a statistically equivalent person from a differentethnic/racial group. The differences in these returns of earnings for human capital characteristics are variously interpreted as proof of some sort of market inequality or, often, as evidence of discrimination.

In addition to measuring income differences, an important difference across groups involves labor force participation, as well as unemployment. Researchers who focus only on earnings or income differences across groups miss differences in overall socioeconomic outcomes that come about because laborers are discouraged in the labor market or are unable to participate. Thus 
comparing income and earnings between groups will miss some of the causes of black poverty, given that black men have a labor force participation rate $8 \%$ lower than that of whites, and their participation is appreciably lower than that of all other groups except for American Indians. The labor force participation rate includes in the denominator individuals who are actively employed, who have a job but are not currently at work, and those who are looking for work. It can be affected by different cultural norms and values regarding women working outside the home, the age structure of a population, the overall health and disability prevalence across a population, and other factors not necessarily measuring "willingness to work." However, as a gross indicator, it tells us something about attachment to the labor force and the discouragement of workers.

In addition, monetary inequality is not the only measure of the lack of equality of outcomes in our society. There are other ways to measure inequality among racial and ethnic groups that we do not have the space to review here, including health and demographic measures such as infant mortality rates, life expectancy, morbidity, and disability. Ethnic and racial groups also differ in rates of home ownership, residential segregation, overall wealth, exposure to crime and toxic pollutants, and in access to power in the upper reaches of our society. In this article we concentrate on income inequality, recognizing that this does not tell a complete story.

\section{THE SITUATION OF BLACK AMERICANS}

How has this current pattern of inequality emerged? The story is somewhat different for the different ethnic categories, because of the varying histories of the groups. For black Americans, the removal of formal legal segregation in the 1960s, along with the rising economic prosperity in that decade, brought rises in weekly or hourly earnings and increased education and returns to education. However, these promising trends have been coupled with changes in family structure that have led to the deterioration of household income for women and children in single-parent families. Growing rates of black male joblessness mean that rising earnings are distributed over a narrowing portion of the potential labor force. Recent developments raise no particular optimism that the wage gains that occurred into the 1970s will quickly eradicate group differences. Economic restructuring in the context of global competition helps to create structural barriers to improvement of the situation of persons with the least education and fewest skills to offer to employers. In addition, evidence suggests that racial discrimination remains an obdurate problem for African Americans regardless of social and economic class.

In $1940,92 \%$ of blacks were poor; by the early 1970 s the black poverty rate had declined to $31 \%$ (Farley 1993). The relative black/white odds of being 
in poverty fell from more than 6:1 in 1930 to less than 4:1 in 1985 (Jaynes \& Williams 1989). Smith \& Welch (1989) estimated that the annual earnings in constant 1987 dollars for a full year, full-time black male worker, inferred from weekly earnings, rose from just under $\$ 5000$ in 1940 to more the $\$ 20,000$ in 1980 , and that black male wages rose from $43 \%$ to $73 \%$ of white male wages in this same period. The ratio for actual annual earnings, given differences in labor supply, in 1980, however, was somewhat less at $62 \%$ (Farley \& Allen 1987).

Economic growth was a primary engine for improving the economic status of both blacks and whites from the end of the depression through the early 1970s (Jaynes \& Williams 1989, Smith \& Welch 1989, Farley 1993). Decompositions of changes in black-white differences show that the lion's share of the explanation for the narrowing of the wage gap for males is attributable to the narrowing in the education gap between blacks and whites, and to declines in the racial disparity in earnings as returns to schooling (Smith \& Welch 1989, Farley \& Allen 1987). Concentration in the south also had a smaller depressive effect on black earnings in 1980 than in 1940, because of redistribution of the black population from the south, but even more because of declining regional wage disparities and racial disparities within the south (Smith \& Welch 1989). White and black distribution to occupations also became more similar across this period. Jaynes \& Williams (1989) reported that from 1950 to 1982, because of shifts in the American occupational structure, the percentage of white men in professional or managerial positions increased from $20 \%$ to $32 \%$, and for black men from $6 \%$ to $20 \%$.

The story about transformations affecting women is different. In 1940, black women had higher rates of labor force participation and employment than did white women. Using census data Farley (1993) estimates that, based on 1940 employment rates, black women have been employed for 14.5 of their 40 years between ages 25 and 64, compared to just 8.8 years for white women. Increases of labor force participation by both black and white women led to increases in years in employment for both groups thereafter. By 1991, Bureau of Labor Statistics data showed that white women's years in employment during these ages would be 24.4 years, compared to 23.7 years for black women. By 1980, earnings ratios had closed for women in most education categories; for women with college degrees the earnings of black women exceeded those for white women (Farley 1993). However preliminary analysis of CPS data for the years 1969 to 1987 by M. Corcoran and S. Parrott (unpublished paper) found that white women's wages grew more rapidly than black women's wages after 1977. Corcoran \& Parrott suggest that as the labor force participation of white women increases, advantages of black women deriving from unmeasured differences in labor force attachment may disappear, unmasking a racial wage gap among women. 
The economic gap between blacks and whites seems unlikely to close soon because the American economy seems to have stalled well short of the mark that would allow full equality. The impact of economic restructuring is particularly acute for those at the bottom of the education and skill distribution where blacks are overrepresented. Many scholars point to declines of middle level jobs (Harrison \& Bluestone 1988), the redistribution of manufacturing jobs away from the central cities where many jobless blacks live (Sassen 1988), and the rise of eamings inequality among workers of all races (Danziger \& Gottschalk 1993) as causes for pessimism about the prospect for rapid future narrowing of the racial gap.

One manifestation of these changes may be that gains in earnings have been offset by a growing racial disparity in joblessness (unemployment and nonparticipation in the civilian labor force) between black and white men (Moss \& Tilly 1991). In part, this increased joblessness reflects the substitution by young black men of "good" activities such as military service and education for work (Mare \& Winship 1984, Smith \& Welch 1989). Yet there is a trend toward relatively high rates of joblessness and nonparticipation in the labor force for African American males even at older ages (Smith \& Welch 1989, Jencks 1991). Changes in the social fabric of some African-American communities, partly a consequence of the narrow opportunity structure for many African Americans, help to perpetuate structural barriers to improvement in the well-being of African Americans. Growing rates of female headship in African-American families have increased racial disparity in incomes and may create difficulties in the socialization of the next generation.

Female headship has been increasing for both black and white families, but especially for blacks. In 1940, 20\% of black families with children under 18 were headed by women; by 1990 this figure had increased to $52 \%$. For white families over the same period, families headed by women increased from $8 \%$ to $17 \%$ (Farley 1993). Because female headship is associated with high rates of poverty, this increase in female headship for blacks has expanded somewhat the disparity in poverty rates for white and black families. Farley estimates that if the 1960 distribution of family type had held in 1980, black poverty rates would then have been $26 \%$ rather than the observed 33\%. Bane (1986) estimated that in 1983 differences in household composition accounted for $44 \%$ of the difference in overall poverty rates between blacks and whites. However, Bane also cautioned that such decompositions could partially be artifacts of selection into household type, and particular caution was advised in the interpretation of trend data.

One important line of research associated with William Julius Wilson (1987) has focused in particular on the effects of these changes on African Americans who live in areas of concentrated poverty in the central city core of metropolitan areas. On the employment side these subpopulations suffer from a lack of 
education and skills and a mismatch between their urban location and the relocation of employment opportunities outside of cities (Kasarda 1985, Wilson 1987). On the social side, Wilson suggests that neighborhood concentrations of the most disadvantaged black populations have propagated destructive attitudes and behaviors that perpetuate the disadvantage, such as high rates of teenage childbearing, female family headship, drug use, illegal market activity, and detachment from the labor force.

A large research literature attempts to model the impact of these "neighborhood" effects-net of personal characteristics - on destructive behaviors and poor social and economic outcomes. These studies have shown inconsistent and generally relatively minor effects (Brooks-Gunn et al 1993, Crane 1991). (For a good overview see Jencks \& Mayer 1990.)

While the emphasis in much of the literature on the social and economic impacts of economic restructuring on the most disadvantaged blacks has considerable justification, Jencks $(1991,1992)$ reminds us that the population that suffers from the full range of problems associated with the concept of the urban underclass is relatively narrowly circumscribed.

Despite the gains that have been made by some middle class and working class blacks in recent decades, there is a strong body of evidence that discrimination remains an important part of the explanation of black-white inequality. Farley \& Allen (1987) show that for a black male there is still an earnings disadvantage at all levels of economic attainment. From studies testing the reaction of employers to job applicants of different races, Kirschenman \& Neckerman (1991) find strong evidence of direct racial discrimination at the point of hiring by white employers. Feagin \& Sikes (1994) show that the experience of racial hostility is routine for African Americans across social classes. These studies suggest that the fact that a particularly heavy share of the burden of current economic changes is bome by poor African Americans is not simply an artifact of the uncompetitive labor market position of many black workers; the civil rights revolution has by no means eradicated racial discrimination in American social and economic life.

\section{AMERICAN INDIANS, HISPANICS, AND ASIANS}

Questions sometimes arise about the prevalence and importance of discrimination to the employment and earnings of Hispanics or Latinos, Asians, as well as Native North Americans. Peoples in these categories are often categorized together with Americans of African descent as peoples of color, or racial minorities, though this attribution is particularly ambiguous for many Latino and Indian Americans given the large volume of intermixing between European and indigenous American peoples. What are the patterns of earnings inequality compared to the white population, and what costs does ascriptive 
discrimination impose, given the historical importance of color consciousness in the United States?

Studies of the labor market experiences of Hispanics as a whole, and of the different subgroups, find that while Hispanics are disadvantaged in the labor market compared to whites, only Puerto Ricans are as severely disadvantaged as blacks and American Indians. Although, overall, Asians have a higher median family income than do American whites $(\$ 41,583$ vs. $\$ 37,630)$ in 1990 , there is a great deal of variation among the subgroups. They range from the severely distressed Hmong population with a median family income of $\$ 14,327$, a poverty rate of $63.6 \%$, and a labor force participation rate of $29.3 \%$ to the successful Japanese with a median family income of $\$ 51,550$ and a poverty rate of only $7 \%$. The longer established Chinese, Japanese, Filipino, and Asian Indians are doing well-better than the white non-Hispanic average. However the Southeast Asian refugees from Laos, Cambodia, and Vietnam are not achieving as well.

What explains this pattern of variation? Multivariate earnings models suggest some evidence of wage and employment discrimination against Hispanics, Native Americans, and Asians, but that it is less important factor than in the case of blacks. For many Asian groups, of course, there is no pattern of net disadvantage to explain, though this result is compatible with the finding of discrimination in returns to education and other human capital attributes. For many Latino groups, problems in the United States reflect in part the attributes of the migrant pool. At a migrant's destination, his/her poor human capital characteristics interact with the effects of American economic restructuring to perpetuate disadvantages. For Asians and Latinos, the characteristics of immigrants and their absorption into the country are an integral part of the story. The regional concentrations and different modes of incorporation of the different subgroups as well as their differing times of arrival and social class backgrounds also help to explain variations in outcomes (Portes \& Truelove 1987, Nelson \& Tienda 1985, Bean \& Tienda 1987). We turn now to an examination of these groups in detail.

\section{American Indians}

The poorest of all the groups in the United States is also the group least influenced by immigration. In 1990, the Census counted 1.96 million American Indians and Alaskan Natives, which makes this the smallest of the four conventional minority categories in the United States. It was also among the poorest-a condition that has been noted by researchers historically (Meriam 1928, Brophy \& Aberle 1966, Levitan \& Hetrick 1971). This poverty has been associated with the underdevelopment of many reservation communities because of their geographical isolation, lack of resources, and political domina- 
tion by federal authorities (Cornell \& Kalt 1990, Snipp 1986, Trosper 1994, White 1983).

Earnings models for Indians confirm sharp wage disparities between Native Americans and white Americans. These are primarily attributable to large differences in human capital. Scholars disagree about whether the data show discrimination effects (Gwartney \& Long 1978, Trosper 1974, Sandefur \& Scott 1983).

One difficult theoretical and policy question about Indian reservation communities concerns the impact of residence on reservations on earnings disadvantages. Standard migration models would anticipate labor outflows exceeding those observed from these resource-poor rural enclaves. For other ethnic populations concentrations of disadvantaged group members such as those found on reservations might be considered evidence for the existence of imposed barriers to exit; for Indian tribes these are taken as an expected consequence of sovereignty. However, using data from the question as to place of residence five years ago on the 1980 census, Snipp \& Sandefur (1988) could not find consistent earnings returns to migration from reservation areas.

\section{Hispanics}

In 1990, persons of Mexican origin formed the largest Hispanic group, numbering nearly 13.5 million persons. Puerto Ricans were the second largest with 2.7 million living on the mainland. There were slightly more than 1 million persons of Cuban origin. There were 5.1 million persons in the composite "Other Hispanic" category, including mostly Central and South Americans and other Caribbean people. Dominicans were the largest group within this category with over 500,000 people.

The outstanding theme characterizing the heterogeneity of Latinos is that Puerto Ricans do exceptionally badly in terms of employment and income, and Cubans do exceptionally well. Puerto Ricans are legally US citizens; they are concentrated in the industrialized northeast and work in industrial jobs. They have the highest proportion of persons living in poverty, show increasing withdrawal from formal labor markets, and have the highest rates of any Latino group of welfare dependency and family disruption (Morales \& Bonilla 1993).

Mexicans have high labor force participation rates, but partly because of their lower overall educational attainment, they work for very low wages. Some of them are illegal immigrants, thought to be a docile and pliable work force, and so preferred by employers.

Many of the Cubans are political refugees, and a large number of them are concentrated in the city of Miami where they have created an enclave economy that provides employment opportunities for other Cubans, even those who speak little English or who are new arrivals (Portes \& Bach 1985).

DeFrietas $(1985,1991)$ shows that unemployment and earnings differentials 
between Hispanics and non-Hispanics depend mostly on differences in worker characteristics. Both Reimers (1985) and Abowd \& Killingsworth (1985) conclude that unequal educational attainment is the major determinant of the observed wage gap. The evidence on educational attainment shows Latinos doing poorly relative to other groups. Comparing college completion rates, Morales \& Bonilla (1993:12) note that between 1980 and 1990 the white population increased college enrollment from $31 \%$ to $39 \%$, African Americans from $28 \%$ to $33 \%$, while Latinos remained level at $29 \%$. However, Harrison $\&$ Bennett (1995) argue that the popular press reports of a crisis in education for Hispanics are overblown. They argue that "native born Hispanics are almost as likely to complete high school as blacks and American Indians; the very low percentage of Hispanic immigrants with high school diplomas reduces the completion rates of the group as a whole."

Standard multivariate studies of economic attainment of Hispanic men and women do show evidence of discrimination. Stolzenberg (1990) found, using the 1976 Survey of Income and Education (SIE), that Hispanics who speak English well and who have completed high school have returns to schooling about equal to white non-Hispanics. However, he did find that less educated Hispanics do have less return to their education than do statistically comparable non-Hispanic men. DeFrietas (1991) used 1980 census data on income in 1979 and found a gap of $10 \%$ or more between Hispanics and non-Hispanics after controlling for age, education, English language ability, nativity, and State/ Metro residence. The Urban Institute found additional evidence of discrimination against Hispanic job applicants in an audit study of employers in Chicago and San Diego (Kenney \& Wissoker 1994).

According to Morales \& Bonilla (1993) changes in the American economy in the last few decades have hit Latinos particularly hard because of their low educational attainment and their labor market positions. Eamings for Latino men, controlled for inflation, actually dropped in the period between 1978 and 1987; in constant dollars they earned an average \$49 per year less in 1987 than in 1978. Morales \& Bonilla attribute part of this decline to the erosion of the minimum wage and the fact that $23.8 \%$ of Latino men were minimum wage workers.

Carnoy et al (1993), using 1980 census and Current Population Survey data from 1982, 1985, and 1987, found a decline in Latino relative incomes for both males and females in the 1980s. They argue that the relatively favorable trends in convergence between Latino and white earnings in the 1960s and 1970s were due to educational increases and a shift in employment from agriculture to manufacturing. They attribute the recent declines to increased numbers of immigrants with low education and English ability and the concentration of Latinos in low-paid service jobs and to the decline of higher-paid manufacturing jobs. Harrison \& Bennett (1995) used a 1990 census data to find that some 
Hispanic men continue to earn less than comparably educated white men. Hispanic men with less than an associate degree earned only $76 \%$ of what white males with equivalent education earned.

The recent trends for women Hispanics as with other women minorities are better than the trends for men. Harrison \& Bennett (1995) found that among all education levels, except among selected cohorts either without high school diplomas or with associate degrees, Hispanic and non-Hispanic white women have achieved parity in earnings. More detailed analyses should be done with 1990 census data for specific Hispanic groups because studies done with earlier data show strong differences by national origin. Reimers (1985), using 1976 SIE data, found that Central and South American men received wage offers $36 \%$ below those for white non-Hispanic men; the differential was $18 \%$ for Puerto Rican men, $12 \%$ for Other Hispanics, and $6 \%$ for Mexicans. Cubans, by contrast, showed a $6 \%$ advantage over white non-Hispanics with a similar background.

Scholars have paid particular attention to the puzzle of high poverty rates and declining labor force participation among Puerto Ricans, despite the "advantage" of US citizenship. The concentration of Puerto Ricans in declining manufacturing jobs, and the possibility of more virulent discrimination against Puerto Ricans of darker complexions are possible explanations, along with the availability of means tested transfer payments, the growth of households headed by women, and the growth of circular migration (Bean \& Tienda 1987, Tienda et al 1992).

Because in $199035.8 \%$ of Hispanics were foreign born, the question of how the new immigrants are affecting the overall standing of Hispanics as a whole and of the different subgroups is an extremely important one. Factors such as changing migration streams, the proportion of workers who are undocumented, and particular economic strategies of the foreign-born affect the overall profile of the different groups.

In the 1980s the group "Other Hispanic" grew at a fast pace through immigration. This growth also contributed greatly to the heterogeneity of the Hispanic population. Many Central Americans from countries like El Salvador, Guatemala, and Nicaragua as well as Caribbean immigrants from the Dominican Republic tend to have limited educations, high poverty rates, and low median family incomes. South American immigrants from countries like Colombia, Peru, and Bolivia have much higher educational attainment, lower poverty rates, and higher incomes.

Undocumented workers, who are disproportionately Latin American, differ from legal immigrants in ways that also reinforce the low income profile of the group. Borjas \& Tienda (1993:712) examined the employment experiences and wages of undocumented workers who applied for and received legalization under the 1986 IRCA amnesty program. They found that the legalized im- 
migrants had higher rates of labor force participation than did the foreign-born population as a whole, exceeding those rates by $5 \%$ for men and $17 \%$ for women. Undocumented workers earned lower wages than legal immigrants-they earned $30 \%$ less than their legal counterparts from the same regional origins.

\section{Asians}

Asian Americans are the fastest growing minority group in the country. The Asian American population doubled in size in the 1980s and now totals 6.9 million, an increase from $1.5 \%$ to $2.9 \%$ of the total US population. This growth was due in great part to immigration. Of Asian Americans $66 \%$ were foreign born in 1990, and $28 \%$ of all Asian Americans entered the United States between 1980 and 1990. Southeast Asians from Vietnam, Laos, and Cambodia had the highest percentages of foreign-born, around $79 \%$. Japanese had the lowest at 32.4\% (Bureau of Census 1993).

Those people classified as Asian in the census and other sources come from a number of different countries with different cultures, languages, and histories. Within national origin groups there are also differences in social class background, timing of arrival, and labor market opportunities (Yamanaka \& McClelland 1994:82).

Part of the explanation of Asian socioeconomic achievement lies in their greater-than-average educational attainment. The lower incomes and higher poverty of Southeast Asians are largely attributable to the much lower average educational attainment of members of these groups. While $23.3 \%$ of the total US male population had a college degree or higher, $48.7 \%$ of Asian Indian men, $41.6 \%$ of Filipino men, and $35 \%$ of Chinese men were college graduates; among Cambodians, Hmong, and Laotians, only 3\% of men had a college degree or higher. Harrison \& Bennett (1995) report that Asians were about two-thirds more likely to have completed college than whites.

This high educational attainment is partly a result of Asian immigration selectivity. Many Asians enter under highly selective immigration criteria. Harrison \& Bennett report that native-born Asians are still substantially more likely to complete college (32\%) than are whites and other groups, but the differential is smaller than for foreign-born Asians.

Though the relatively high education and earnings of many Asian groups mean that these groups do not suffer the same magnitude of disadvantages as many other groups, there is some evidence that returns to education are lower for Asian Americans than for whites, though this pattern may be changing (Hirschman \& Wong 1984, Wong 1986). Asian men and women needed more education to receive the same income as whites. This can be attributed to discrimination in the higher end of the occupational structure (the glass ceiling effect) or to other unobservable human capital differences in things like quality of schooling or English language skills. 
Hirschman \& Wong (1984:584) analyzed 1960 and 1970 census data and 1976 SIE data for Japanese, Chinese, and Filipinos, as well as for other non-Asian groups. They found a marked decline in the direct negative effect of ethnicity on eamings (except among Chinese). They speculate that perhaps Chinese Americans do worse than others because the enclave of Chinatown serves as a funnel that directs Chinese Americans into low paying jobs. (This hypothesis is revisited when we review the more recent debate about the effects of ethnic enclaves on returns to education.) However, Hirschman \& Wong found that there still were costs associated with Asian ethnicity-when adjusted for background variables, all groups except the Japanese had incomes somewhat less than comparable whites. Japanese men actually earned more than comparable white men in 1976. In a similar study, Wong \& Hirschman (1983) found that Asian women had higher incomes overall than whites because they had higher amounts of education, lived in higher income areas, and were younger overall than whites.

In a multivariate study of income by education and by occupation, Barringer et al (1993:265) found that when other factors were controlled, "whites eamed more than Asian Americans in almost all occupational categories except in the professions, where Asian Americans had much higher incomes, but even there they bested whites only among the self employed." They conclude that Asian Americans are highly educated and convert that education into high status occupations, but nevertheless they are paid less than whites for the same or comparable positions (Barringer et al 1993:266).

Recent evidence from the 1990 census shows that Asian returns to education are approaching those of non-Hispanic whites at upper levels of education. Compared to other minorities, Asians are approaching parity in their ability to convert their educational status into income and occupational standing, at $92 \%$ and $97 \%$ of comparable whites for the annual and hourly earnings of Asians with graduate degrees (Harrison \& Bennett 1995). However, these analyses were not broken down by specific national origin groups.

Much of the literature on Asian Americans concerns the question of whether Asians' success makes them a "model minority" whose high education and income are due to cultural factors and hard work, which allow them to rise above adversity (Kitano 1976). The academic achievement of Asian American children, and the more stable family structure of Asian Americans, compared to other groups in America, are cited as examples of the ways their overall cultural values lead to success. Researchers critical of the success model of understanding Asian Americans stress:

1. The heterogeneity of the Asian population, the economic distress of Southeast Asian refugees, and the existence of unskilled workers employed in the low end of the split labor market (Poston 1988, 1994, Hein 1993, Lee 
1989). These authors stress that there are dangers in viewing all Asians as successful, because the extreme poverty of Southeast Asians and the poverty of low skilled members of other groups will then not receive the public policy interventions that are needed.

2. The extra effort and household strategies Asian Americans are forced to use to overcome continuing discrimination, and the costs of that effort (Caplan et al 1989, Kibria 1994, Rumbaut 1989, Yamanaka \& McClelland 1994, Hurh \& Kwang 1989, Espenshade \& Ye 1994). These researchers stress the fact that many Asians avoid extreme poverty or welfare dependence through hard work and long hours that take physical and psychic tolls on individuals and families. Also families survive by dispatching many workers into the economy and by combining wage labor, government transfers, and other creative strategies to get by.

3. The specific problems faced by Asian entrepreneurs (Min 1990). These include long hours and combining many family workers in one household, as well as facing the physical dangers of crime in shops in inner city neighborhoods, and the racial tensions, boycotts, and even riots such as those faced by Korean shop owners in black neighborhoods.

While all of these criticisms of the blind equation of Asian Americans with socioeconomic success are valid, the fact remains that many Asian Americans are doing as well, or better than, whites. Southeast Asians are not doing well overall-however, these refugees came with little formal education and little preparation for their move to the United States. The question of what will happen to their children-the second generation-is a very important one for this debate. Caplan et al $(1989,1991)$ cite the educational success of the children of the boat people as a hopeful sign that there will be a great deal of economic mobility. In fact they cite the educational success of children of boat people as "truly startling and extraordinary" (although their study did not include the severely distressed Cambodians and Hmong). If the children of the Southeast Asian boat people do show enormous socioeconomic mobility and high educational attainment in the future, this will indeed call forth the model minority descriptions, and it will be up to analysts to revisit the debate.

\section{NEW IMMIGRANTS AND NATIVE MINORITIES}

Perhaps the most perplexing question about the current pattern of racial and ethnic inequality in the United States is how-given the economic restructuring and loss of manufacturing jobs that have occurred-some new immigrants manage to do well in the labor force compared to native minorities? Portes \& Zhou (1992:498) describe this as the "peculiar American paradox of rising labor market marginalization of native-born blacks and Puerto Ricans, along 
with growing numbers and employment of third world immigrants" (see also Sassen 1988). This is related to the important policy question of whether the foreign-born take jobs from native minorities. Another question that motivates research in this area is why some immigrants seem to do better than othershow to explain the relative success of Cubans or East Indians compared to Puerto Ricans or Vietnamese?

The classic economic approach to understanding the incorporation of immigrants has been to measure individual level data on human capital endowments such as education, language ability, and the like, and then assess the returns of wages and earnings to those human capital characteristics. The standard model (such as in Chiswick 1979) finds that the longer immigrants are present in the United States labor force, the more their initial earnings disadvantage is overcome. Chiswick found that the crossover point when the foreign-born equal or surpass the native-born is 15 years.

The current debate about immigrants and their human capital skills revolves around the argument of Borjas $(1990,1991)$ that the average skill levels or "quality" of immigrants has declined over time. This is important for understanding the assimilation process of immigrants because of the frequently used assumption that convergence between foreign-born and native-born wages and earnings equals assimilation. If it is assimilation, recent immigrants would be expected to catch up to or crossover the earlier immigrants and natives. However, if recent immigrants are of lower overall quality than earlier immigrants, then the progress seen in cross-sectional data is illusory, and more recent immigrants would be expected to have lower earnings than natives permanently.

Borjas' conclusions have been criticized on a number of points, including a failure to take into account emigration by the less successful foreign-bom, (Jasso \& Rosenzweig 1990) and the confusion of "immigrant quality" with national origin differences and differences in contexts of reception and modes of incorporation. As Tienda (1983b) points out, the standard human capital approach, with its emphasis on individual differences, does not explain why, after extensive controls for various determinants of earnings, there persist differences in the rate at which foreign workers of differing national origins reach income parity with the native-born population. For instance Poston (1994) in an analysis of economic attainment among foreign-born men, finds that men from European origins do much better than those from other regions of the world. He also finds that refugees-turned-immigrants from places such as El Salvador, Guatemala, Haiti, Honduras, Laos, Nicaragua, Panama, and Vietnam are not doing as well as economic immigrants from other countries in terms of their economic attainment.

Tienda (1983b) and Portes \& Rumbaut (1990) argue for an analysis based on looking at the mode of incorporation or context of reception that different 
national origin groups face. The very evaluation of worker characteristics by employers is often not done on an individual basis but is affected by things like the degree of ethnic concentration of particular groups, and the degree of prejudice toward those groups present in American culture. The national origin differences Borjas finds in returns to human capital may be due to some unobservable individual characteristic that is a measure of "quality", or it may be due to some group level characteristics, such as the effects of ethnic networks on economic incorporation, or discrimination in the form of hiring queues, lesser pay for equal work, or some other sort of differential reaction on the part of American society based on something other than individual characteristics. Lieberson (1980) showed that greater concentrations of particular ethnic groups in a particular labor market increased the chances for competition and discrimination against those groups (see also Tienda \& Wilson 1992). Later cohorts by definition face greater concentrations of their group as they join earlier migrants from their ethnic groups.

An approach that emphasizes the social as well as the economic context of the reception of immigrants includes an analysis of community level variables that condition the kinds of achievement individuals experience (Portes \& Zhou 1992). An example of this approach is the discussion of the ethnic enclave as a pathway for mobility for immigrants.

\section{The Enclave Debate}

When immigrants enter a new society they often face barriers to full inclusion in the economic activities of the host society. Besides through outright discrimination, this occurs, for example, because of the absence of network ties necessary to gain access to or to succeed in certain kinds of activities, because of barriers to entry to professional or internal labor markets that have the effect of excluding those with foreign credentials, because the skills of immigrants are concentrated in specific occupations, and because these skills may not be well matched to the needs of the employers in the host society.

An immigrant group's economic standing depends in part on the way in which it overcomes these barriers to become incorporated into the economy. Often entrepreneurism has been an avenue. A consistent finding in the examination of immigrant earnings and employment is the overrepresentation of immigrants in entrepreneurial activities, and a positive relationship between self-employment and income (Portes \& Zhou 1992:495). The involvement of immigrants in small business has been investigated by a number of scholars including Light (1973), Bonacich (1973), Light \& Bonacich (1988), Waldinger (1986, 1989), and Waldinger et al (1990). The ethnic enclave (first defined by Wilson \& Portes 1980 and Portes \& Bach 1985) is a particularly important avenue of mobility for Cuban Americans. The enclave is defined as a concentration of ethnic firms in physical space-generall metropolitan area-that 
employ a significant proportion of workers from the same minority" (Portes \& Jensen 1992:418).

Portes and his associates have argued that the enclave allows immigrants to find employment that brings better returns to their human capital than would be found in the secondary labor market outside of the enclave, and that it is therefore beneficial for workers as well as employers. They cite the Cuban enclave in Miami as an example of the use of an enclave as an unorthodox mobility path that in part explains the relative success of Cubans compared to other Hispanics. This view of the ethnic enclave has direct implications for long-held assumptions about assimilation. The argument is that people who stay within the ethnic enclave do better than those who leave it for employment, which is of course in direct contradiction to an assimilation model that would posit greater success for those leaving the ethnic concentration.

The enclave hypothesis has engendered a great deal of debate. While Portes \& Jensen $(1987,1989)$ see the enclave as offering opportunities for economic mobility, Sanders \& Nee $(1987,1992)$ see it as an ethnic mobility trap. These authors conducted an analysis of census data on Cubans in Miami and Chinese in California and concluded that while employers may be better off in the enclave economy, workers were not better off and may be exploited by their co-ethnic employers.

One difficulty with the debate about the impact of enclaves is that limitations of the census data that have formed the basis of many of the studies make it difficult to operationalize theoretical concepts directly. Different researchers have also used different definitions of the enclave, defining it by place of work (Portes \& Jensen 1989, 1992) or place of residence (Sanders \& Nee 1987, 1992). Zhou \& Logan (1991) operationalized the enclave in three different ways, as place of residence, place of work, and place of industry. Using place of residence as the definition of the Chinese enclave in New York, they found positive returns for human capital for workers both inside and outside the enclave. Zhou \& Logan also raise the possibility that some enclave economies provide better opportunities than others and that there may be gender differences in the operation of enclave effects.

Logan et al (1994) point out that the ethnic enclave is a relatively rare phenomenon, characterizing the Cubans in Miami, Los Angeles, and Jersey City, Mexicans in Los Angeles and Houston, Chinese in New York, San Francisco, and Los Angeles, Koreans in Los Angeles, and Japanese in Los Angeles, San Francisco, San Jose, Anaheim, and Honolulu. Many other cities have large numbers of minorities without a spatial overrepresentation of an ethnic group corresponding to an ethnic enclave. This uneven pattern of enclave development across different cities and different ethnic groups is an intriguing one, worthy of further research investigating the mechanisms by which enclaves become established. 
Research about the structuring and impact of ethnic enclaves constitutes an important part of the agenda for the study of the incorporation of immigrant ethnic groups. While we do not agree with Waldinger (1993) that the term ethnic enclave should be abandoned because of the difficulty of definition and measurement, we do believe that many of the central questions about its operation are dependent not on further analyses of census data, but on gathering new data with direct measurements of theoretically relevant variables of the sort gathered by Portes \& Bach (1985).

\section{Implications of Immigration for Native Minorities}

Another important set of questions about immigrants concerns their impact on native minorities. Immigrants have higher rates of entrepreneurship and labor force participation than do blacks and Puerto Ricans in the nation's cities, and lower rates of unemployment. Do immigrants take jobs from native minorities? Jackson (1983) cites the possibilities for increased interethnic tensions if immigrants succeed and leave America's longtime resident minorities behind. Some of the popular media suggested the stress caused by competition for jobs was one reason behind ethnic tensions that surfaced in the 1992 Los Angeles uprising (Muller 1993:197).

Despite these expectations, at the aggregate level, econometric studies show that immigrants do not compete with native workers and do not decrease their wages or employment levels (Borjas \& Tienda 1987, Borjas 1990, LaLonde \& Topel 1991). Muller (1993:181) argues that middle class blacks in gateway cities such as New York, Chicago, and Los Angeles experience upward mobility into professional and managerial sectors at rates higher than they do in cities without immigrants. However, certain industry case studies and local area studies have found substitution and competition (Waldinger 1986, Bailey 1987, Waters 1994).

Various explanations have been advanced to account for the finding that immigrants do not take jobs from native minorities. The bimodal distribution of skills among immigrants means that some immigrants arrive with high education and skills. These immigrants do not compete with those members of native minorities who are overrepresented at the lower end of the skill distribution, and they may even begin businesses that then create jobs for native workers. Simon (1989) also argued that consumption by immigrants stimulates the economy, because immigrants upon arrival begin consuming before they are employed, thus increasing demands for goods and services even if they do not find employment. However, the effect is likely negligible at best.

Waldinger's (1994) work on immigrants and natives in New York City shows that the establishment of ethnic networks and the decline in the population of native whites leads to the establishment of ethnic niches in employment and job vacancies that defuse immigrant native competition. 
One important line of research studies the effect of unskilled immigrants on the employment of unskilled natives. Many reason that illegal immigrants accept lower wages and worse working conditions because of their need to work and avoid detection by immigration authorities, and because conditions of employment considered substandard in the United States exceed those available at the margin in many countries of origin.

In the economics literature, a standard approach to the study of the effect of immigrants on native workers is to treat different analyses of cities within the United States as distinct labor markets and to compare labor market outcomes across cities with higher and lower immigrant densities. Using this approach, Butcher \& Card (1991) examine whether the declines in the 1980s of the real earnings of the least skilled workers in the US economy were related to immigration. They found that while the rise in wage inequality in the 1980s was bigger in cities with relatively bigger immigrant inflows, immigration was more associated with growth in wages at the high end for workers than in decline of wages at the low end.

Muller (1993) finds a negative correlation between blacks' income and the percentage of immigrants and between black youth unemployment and immigration. He concludes that either immigrants create economic growth, which in turn improves job prospects for blacks, or that Mexicans and Asians as well as blacks are all attracted to urban areas where employment opportunities are growing.

One possibility is that unskilled native workers migrate out of cities where immigrant workers are arriving. Filer (1992) analyzed population movements between 1975 and 1980 and found that intercity migration decisions of natives were sensitive to immigrant growth, and that immigrant arrivals are almost completely offset by native outflows. However, Butcher \& Card (1991) find the opposite in their analysis of native migration and immigrants in the 1980s. These authors conclude that there is a positive link between immigrant inflows and net native in-migration.

Although these aggregate comparisons across cities do not show effects on unskilled native minorities of a rise in immigration, this does not mean that there are not substitution effects in particular occupations, industries, or work sites. Many black Americans believe that they are losing jobs to immigrant workers (Waters 1994). In a survey of hiring practices among Chicago area employers, Kirschenman \& Neckerman (1991) found strong employer preferences in hiring decisions for immigrants over inner city blacks (see also Muller 1993:179). Substitution of immigrants for blacks in unskilled work sites might take place in ways that are difficult to measure directly. For instance large numbers of immigrants available to do contract work or working in small enterprises might affect the ability of cities and industries to hire nonunion contractors to do work previously done by unionized workers. Blacks who had 
been employed in unionized public work sectors could suffer as a result (Muller 1993).

These aggregate studies based on correlations between presence of immigrants and black employment and earnings in specific cities do not make clear whether blacks might have done better had immigrants not been present, and had there been economic growth. Employers may have been forced to raise wages for low skilled jobs, which might have made them more attractive to native workers.

Given the stagnation of movement toward closing the wage gap between blacks and whites, the fact that many immigrant groups do better than native populations, and the historical tendency of native labor to look warily on immigrant competition, questions about the role of immigrants on disadvantaged native minorities seem likely to generate continuing interest. One important area for research in the future is reconciling the perception by many unskilled minority workers that immigrants take jobs from them with the econometric findings that substitution is not occurring.

\section{The Second Generation}

Because new immigrants are predominantly nonwhite, the success of some new immigrants relative to native minorities leads to an intriguing question about the future of the children and grandchildren of the immigrants. Will they follow some of the more hopeful patterns of success and mobility that seem to characterize their parents? Or will they experience downward social mobility as they join America's native nonwhite minority in disproportionate poverty, low skilled work, and unemployment? While there have been no wide-scale studies of the second generation of the post-1965 immigrants, recent years have produced a number of case studies and a few thoughtful and important hypotheses about the experiences of the second generation.

Gans (1990) suggests that in contrast to the children of European immigrants early in this century, the second generation of post-1965 immigrants may well experience socioeconomic decline relative to their parents because of the much changed opportunity structure in the American economy. He outlines several scenarios of possible socioeconomic and social integration of this new second generation. He hypothesizes that some of the children of the immigrants might "Americanize" by adopting the negative attitudes of many American youths toward the low-level, low-pay jobs to which they, like their parents, appear to be confined. On the other hand, some may remain tied to their parents' ethnic community and values; by rejecting the negative attitudes toward school, opportunity, hard work, and the "American dream" that some among the native poor have adopted, these children may end up doing better. If this is true, the ironic result may well find "the people who have secured an economically viable ethnic niche acculturating less than did the European 2nd and 3rd 
generations" (Gans 1990:188), and those without such a niche may become American but experience downward social mobility and reclassification as "undeserving members of the so-called underclass" (Gans 1990:183).

Portes \& Zhou (1993) make a similar argument. They argue that the mode of incorporation of the first generation creates differential opportunities and cultural and social capital in the form of ethnic jobs, networks, and values that create differential pulls on the allegiances of the second generation.

For immigrant groups who face extreme discrimination in the United States and who are close in proximity to American minorities who have faced a great deal of discrimination, "reactive ethnicity" emerges in the first generation. For groups who come with strong ethnic networks, access to capital, and with fewer ties to minorities in the United States, "linear ethnicity" develops. Groups with linear ethnicity may resist acculturation in the United States and end up providing better opportunities for the second generation through the "social capital" created through ethnic ties. The second generation of those with reactive ethnicity, by contrast, are likely to develop the "adversarial stance" toward the dominant white society that American minorities such as poor blacks and Hispanics hold. They conclude: "Children of nonwhite immigrants may not even have the opportunity of gaining access to middle class white society, no matter how acculturated they become. Joining those native circles to which they do have access may prove a ticket to permanent subordination and disadvantage" (Portes \& Zhou 1993:96). These hypotheses rest on notions of network ties, community resources, and social capital that require in-depth study among both native minority groups and the second generation. Because the census no longer asks a question about birthplace of parents (last asked in the 1970 census) the second generation disappears statistically into the native minority population. This is a serious problem in assessing overall trends of assimilation and success for the post-1965 immigrant cohort, as well as in measuring negative or positive impacts of immigrants on native-born minorities. Determining which of the scenarios outlined by these analysts actually will occur will be dependent on careful ethnographic research in these communities, on gathering detailed and expensive survey data, and on reinstituting the census question on parental birthplace.

\section{CONCLUSION}

The research literature on ethnic inequality reviewed here shows that progress in narrowing the gap between minorities and whites and among white ethnics was made when the economy was expanding through the mid-1970s. After that, for many groups, the progress slowed, stopped, or reversed. The restructuring of the American economy in the last few decades has hit many unskilled minority workers hard. In addition, the evidence indicates that direct discrim- 
ination is still an important factor for all minority subgroups except very highly educated Asians. The large numbers of immigrants entering the United States in recent decades have had mixed success, but there are some intriguing ways in which immigrants seem to have achieved mobility in spite of hard economic times and nonwhite status.

In addition to the questions and data needs described in the above discussions of the second generation and of the ethnic enclave, we see some additional important avenues for further research. These include the unraveling of the separate and interactive effects of gender and race/ethnicity, an analysis of the involvement of immigrants in affirmative action programs, and the effects any such involvement may have on native minorities. In addition a sustained look is needed at the question of what continues to cause direct labor market discrimination by employers in favor of whites and immigrants over blacks in hiring decisions.

\section{ACKNOWLEDGMENTS}

We are grateful to Sarah Song for research assistance, and to Lynne Farnum and Victoria Kent for secretarial assistance.

Any Annual Review chapter, as well as any article cited in an Annual Review chapter, may be purchased from the Annual Reviews Preprints and Reprints service. 1-800-347-8007; 415-259-5017; email: arpr@class.org

\section{Literature Cited}

Abowd JM, Killingsworth MR. 1985. Employment, wages, and earnings of Hispanics in the Federal and non-Federal sectors: methodological issues and their empirical consequences. See Borjas \& Tienda 1985, pp. $77-126$

Alba R. 1990. Ethnic Identity: The Transformation of White America. New Haven: Yale Univ. Press

Bailey T. 1987. Immigrants and Native Workers: Contrasts and Competition. Boulder: Westview

Bane MJ. 1986. Household composition and poverty. In Fighting Poverty: What Works and What Doesn't, ed. SH Danziger, DH Weinberg, pp. 209-31. Cambridge: Harvard Univ. Press

Barringer H, Gardner RW, Levin MJ. 1993. Asians and Pacific Islanders in the United States. New York: Russell Sage Found.

Bean FD, Tienda M. 1987. The Hispanic Pop. ulation of the United States. New York: Russell Sage Found.

Bonacich E. 1973. A theory of middlemen minorities. Am. Sociol. Rev. 37:547-59
Borjas GJ. 1990. Friends or Strangers: The Impact of Immigrants on the U.S. Economy. New York: Basic

Borjas GJ. 1991. Immigrants in the U.S. labor market 1940-1980. AEA Pap. Proc. 81(2): 287-91

Borjas GJ, Tienda M, ed. 1985. Hispanics in the U.S. Economy. Orlando: Academic

Borjas GJ, Tienda M. 1987. The economic consequences of immigration. Science 235:64552

Borjas GJ, Tienda M. 1993. The employment and wages of legalized immigrants. Int. Migration Rev. 27(4):712-47

Brooks-Gunn J, Duncan G, Klebanov PK, Sea-

land N. 1993. Do neighborhoods influence child and adolescent development? Am. J. Sociol. 99:353-96

Bureau of the Census. 1993. Census of Population. 1990. Social and Economic Characteristics CP-2-1. US Dep. Commerce. Washington, DC: USGPO

Butcher KF, Card D. 1991. Immigration and wages: evidence from the 1980's. AEA Pap. Proc. 81(2):292-96 
Caplan N, Choy MH, Whitmore JK. 1991. Children of the Boat People: A Study of Educational Success. Ann Arbor: Univ. Mich. Press

Caplan N, Whitmore JK, Choy MH. 1989. The Boat People and Achievement in America: A Study of Family Life, Hard Work, and Cultural Values. Ann Arbor: Univ. Mich. Press

Carnoy M, Daley HM, Ojeda RH. 1993. The changing position of Latinos in the US labor market since 1939. See Morales \& Bonilla 1993, pp. 28-54

Chiswick B. 1979. The economic progress of immigrants: some apparently universal patterns. In Contemporary Economic Problems, ed. W Fellner, pp. 357-99. Washington, DC: Am. Enterprise Inst.

Comell SE, Kalt JP. 1990. Pathways from poverty: economic development and institution building on American Indian reservations. Am. Indian Cult. Res. J. 14:89-125

Crane J. 1991. Effects of neighborhoods on dropping out of school and teenage childbearing. In The Urban Underclass, ed. C Jencks, PE Peterson, pp. 299-320. Washington, DC: Brookings Inst.

Danziger S, Gottschalk P, eds. 1993. Uneven Tides: Rising Inequality in America. New York: Russell Sage Found.

Davis FJ. 1991. Who Is Black? One Nation's Definition. University Park, PA: Penn. State Univ. Press

DeFrietas G. 1985. Ethnic differentials in unemployment among Hispanic Americans. See Bor jas \& Tienda 1985, pp. 127-60

DeFrietas G. 1991. Inequality at Work: Hispanics in the U.S. Labor Force. New York: Oxford Univ. Press

Eschbach K. 1995. The enduring and vanishing American Indian: American Indian population growth and intermarriage in 1990. Ethnic Racial Stud. 18:89-108

Espenshade TJ, Ye W. 1994. Differential fertility within an ethnic minority: the effect of trying harder among Chinese American women. Social Prob. 41(1):97-113

Farley R. 1993. The common destiny of blacks and whites. In Race in America: The Struggle for Equality, ed. H Hill, JE Jones, pp. 197233. Madison: Univ. Wisc.

Farley R, Allen WR. 1987. The Color Line and the Quality of Life in America. New York: Russell Sage Found.

Feagin JR, Sikes MP. 1994. Living with Racism: The Black Middle-Class Experience. Boston: Beacon Press.

Filer RK. 1990. The impact of immigrant arrivals in migratory patterns of native workers. In Immigration and the Work Force: Economic Consequences for the United States and Source Areas, ed. G Borjas, R Freeman, pp. 245-69. Chicago: Univ. Chicago Press
Gans HJ. 1979. Symbolic ethnicity: the future of ethnic groups and cultures in America. Ethnic Racial Stud. 2:1-20

Gans HJ. 1990. Second generation decline: scenarios for the future economic and ethnic futures of the post-1965 American immigrants. Ethnic Racial Stud. 15:173-92

Greeley AM. 1974. Ethnicity in the United States. New York: Wiley

Gwartney JD, LongJE. 1978. The relative earnings of blacks and other minorities. Indust. Lab. Relat. Rev. 31:336-46

Harrison RJ, Bennett C. 1995. Racial and ethnic diversity. In State of the Union: American in the 1990s, Vol. 2. Social Trends. ed. R Farley, pp. 141-210. New York: Russell Sage Found.

Harrison B, Bluestone B. 1988. The Great $U$ Turn: Corporate Restructuring and the Po. larization of America. New York: Basic

Hein J. 1993. Refugees, immigrants and the state. Annu. Rev. Sociol. 19:43-59

Hirschman C. 1983. The melting pot reconsidered. Annu. Rev. Sociol. 9:397-423

Hirschman C, Wong MG. 1984. Socioeconomic gains of Asian Americans, blacks and Hispanics: 1960-1976. Am. J. Sociol. 90: 584-607

Hout M, Goldstein J. 1994. How 4.5 million Irish immigrants became 40 million Irish Americans: demographic and subjective aspects of the ethnic composition of white Americans. Am. Sociol. Rev. 59:64-83

Hurh WM, Kim KC. 1989. The success image of Asian Americans: its validity, and its practical and theoretical implications. Ethnic Racial Stud. 12(4):512-37

Jackson K. 1983. The old minorities and the new immigrants: understanding a new cultural idiom in U.S. history. See MM Kritz 1983, pp. 317-35

Jasso G, Rosenzweig MR. 1990. Self selection and the earnings of immigrants: comment. Am. Econ. Rev. 80(1):298-304

Jaynes GD, Williams RM, eds. 1989. A Common Destiny: Blacks and American Society. Washington, DC: Natl. Acad. Press

Jencks C. 1991. Is the American underclass growing? In The Urban Underclass, ed. C Jencks, PE Peterson, pp. 28-100. Washington, DC: Brookings Inst.

Jencks C. 1992. Rethinking Social Policy: Race, Poverty, and the Underclass. Cambridge: Harvard Univ. Press

Jencks C, Mayer SE. 1990. The social consequences of growing up in a poor neighborhood. In Inner City Poverty in the United States, ed. LE Lynn, MGH McGeary, pp. 111-86. Washington, DC: Natl. Acad. Press.

Kalmijn M. 1993. Trends in black/white intermarriage. Soc. Forces 72:1 19-46

Kasarda J. 1985. Urban change and minority opportunities. In The New Urban Reality, ed. 
PE Peterson, pp. 33-68. Washington, DC: Brookings Inst.

Kenney GM, Wissoker DA. 1994. An analysis of the correlates of discrimination facing young Hispanic job seekers. Am. Econ. Rev. 84(3):674-83

Kibria N. 1994. Household structure and family ideologies: the dynamics of immigrant economic adaptation among Vietnamese refugees. Social Prob. 41(1):301-15

Kirschenman J, Neckerman KM. 1991. "We'd love to hire them, but...": the meaning of race for employers. In The Urban Underclass, ed. C Jencks, PE Peterson, pp. 28-100. Washington, DC: Brookings Inst.

Kitano H. 1976. Japanese Americans: The Evolution of a Subculture. Englewood Cliffs, NJ: Prentice Hall

Kritz MM, ed. 1983. U.S. Immigration and Refugee Policy: Global and Domestic Issues. Lexington, Mass: Lexington

LaLonde R, Topel RH. 1991. Immigrants in the American labor market: quality assimilation and distributional effects. AEA Pap. Proc. 81(2):297-302

Lee SM. 1989. Asian immigration and American race relations: from exclusion to acceptance? Ethnic Racial Stud. 12(3):368-91

Lieberson S. 1980. A Piece of the Pie: Blacks and White Immigrants Since 1880. Berkeley, CA: Univ. Calif. Press

Lieberson S, Waters MC. 1988. From Many Strands: Ethnic and Racial Groups in Contemporary America. New York: Russell Sage Found.

Light I. 1973. Ethnic Enterprise in America: Business and Welfare among Chinese, Japanese and Blacks. Berkeley, CA: Univ. Calif. Press

Light I, Bonacich E. 1988. Immigrant Entrepeneurs: Koreans in Los Angeles, 1965 1982. Berkeley: Univ. Calif. Press

Logan JR, Alba R, McNulty T. 1994. Ethnic economies in metropolitan regions: Miami and beyond. Soc. Forces 72(3):691-724

Mare RD, Winship C. 1984. The paradox of lessening racial inequality and joblessness among black youth: enrollment, enlistment and employment, 1964-1981. Am. Sociol. Rev. 49(1):39-55

Min PG. 1990. Problems of Korean immigrant entrepreneurs. Int. Migration Rev. 24(3): 436-55

Morales R, Bonilla F, ed. 1993. Latinos in a Changing U.S. Economy. Newbury Park, CA: Sage

Moss P, Tilly C. 1991. Why Black Men are Doing Worse in the Labor Market: A Review of Supply-Side and Demand-Side Explanations. New York: Soc. Sci. Res. Coun.

Muller T. 1993. Immigrants and the American City. New York: New York Univ. Press

Myrdal G. 1944. An American Dilemma: The
Negro Problem and Modern Democracy. New York: Harper Bros.

Nelson C, Tienda M. 1985. The structuring of Hispanic ethnicity: historical and contempoary perspectives. Ethnic Racial Stud. 8:49-74 Portes A, Bach RL. 1985. Latin Journey: Cuban and Mexican Immigrants in the United States. Berkeley, CA: Univ. Calif. Press

Portes A, Jensen L. 1987. What's an ethnic enclave? The case for conceptual clarity. Am. Sociol. Rev. 52:768-71

Portes A, Jensen L. 1989. The enclave and the entrants: patterns of ethnic enterprise in Miami before and after Mariel. Am. Sociol. Rev. 54:929-49

Portes A, Jensen L. 1992. Reply to Sanders and Nee: disproving the enclave hypothesis. Am. Sociol. Rev. 57:418-20

Portes A, Rumbaut RG. 1990. Immigrant America: A Portrait. Berkeley, CA: Univ. Calif. Press

Portes A, Truelove C. 1987. Making sense of diversity: recent research on Hispanic minorities in the United States. Annu. Rev. Sociol. 13:359-85

Portes A, Zhou M. 1992. Gaining the upper hand: economic mobility among immigrant and domestic minorities. Ethnic Racial Stud. 15(4):491-521

Portes A, Zhou M. 1993. The new second generation: segmented assimilation and its variants. Annals, AAPSS 530:74-96

Poston DL. 1988. The socioeconomic attainment patterns of Asian Americans. J. Sociol. 19:213-34

Poston DL. 1994. Patterns of economic attainment of foreign born male workers in the U.S. Int. Migration Rev. 28(3):478-500

Reimers CW. 1985. A comparative analysis of the wages of Hispanics, blacks, and nonHispanic whites. See GJ Borjas, M Tienda, pp. 27-76

Rumbaut R. 1989. Portraits, patterns and predictors of the refugee adaptation process. In Refugees as Immigrants: Cambodians, Laotians and Vietnamese in America, ed. D Haines, pp. 138-82. Totowa, NJ: Rowman \& Littlefield

Sanders JM, Nee V. 1987. Limits of ethnic solidarity in the enclave economy. Am. Sociol. Rev. 52:745-67

Sanders JM, Nee V. 1992. Comment on Portes and Jensen: problems in resolving the enclave economy debate. Am. Sociol. Rev. 57: 415-18

Sandefur GD, Scott WJ. 1983. Minority group status and the wages of Indian and black males. Soc. Sci. Res. 15:347-71

Sassen S. 1988. The Mobility of Labor and Capital: A Study in International Investment and Labor Flow. New York: Cambridge Univ. Press 
Simon J. 1989. The Economic Consequences of Immigration. Oxford: Basil Blackwell

Smith JP, Welch FR. 1989. Black economic progress after Myrdal. J. Econ. Lit. 28:51964

Snipp CM. 1986. The changing political and economic status of American Indians: from captive nations to internal colonies. Am. J. Econ. Sociol. 45:145-58

Snipp CM. 1989. American Indians: The First of This Land. New York: Russell Sage Found.

Snipp CM, Sandefur GD. 1988. Earnings of American Indians and Alaska Natives: the effects of residence and migration. Soc. Forces 66:994-1008

Stolzenberg RM. 1990. Ethnicity, geography and occupational achievement of Hispanic men in the U.S. Am. Sociol. Rev. 55:143-54

Tienda M. 1983a. Nationality and income attainment among native and immigrant Hispanic men in the United States. Sociol. Q. 24:253-72

Tienda M. 1983b. Socioeconomic and labor force characteristics of U. S. immigrants: issues and approaches. See M Kritz 1983, pp. 211-31

Tienda M, Donato KM, Cordero-Guzman $\mathrm{H}$. 1992. Schooling, color and the labor force activity of women. Soc. Forces 71(2):365-95

Tienda M, Wilson FD. 1992. Migration and the earnings of Hispanic men. Am. Sociol. Rev. 57:661-78

Trosper RL. 1974. The economic impact of the allotment policy on the Flathead Reservation. PhD thesis. Harvard Univ. Cambridge, Mass.

Trosper RL. 1994. Who is subsidizing whom? In American Indian Policy: Self-Governance and Economic Development, ed. LH Letgers, FJ Lyden, pp. 175-90. Westport, CT: Greenwood

Waldinger R. 1986. Through the Eye of the Needle: Immigrants and Enterprise in New York's Gannent Trades. New York: New York Univ. Press
Waldinger R. 1989. Structural opportunity or ethnic advantage? Immigrant business development in New York. Int. Migration Rev. 23(1):48-72

Waldinger R. 1993. The ethnic enclave debate revisited. Int. J. Urban Regional Res. 17: 444-53

Waldinger R. 1994. The making of an immigrant niche. Int. Migration Rev. 28(1):3-30

Waldinger R, Aldrich H, Ward R, et al. 1990. Ethnic Entrepeneurs: Immigrant Business in Industrial Societies. Newbury Park, NJ: Sage

Warner WL, Srole L. 1945. The Social Systems of American Ethnic Groups. New Haven, CT: Yale Univ. Press

Waters MC. 1994. West Indian immigrants, African Americans and Whites in the workplace. Presented at Annu. Meet. Am. Sociol. Assoc., Los Angeles

White R. 1983. The Roots of Dependency: Subsistence, Environment and Social Change Among the Choctaws, Pawnees, and Navajos. Lincoln, NB: Univ. Nebr.

Wilson KL, Portes A. 1980. Immigrant enclaves: an analysis of the labor market experiences of Cubans in Miami. Am. J. Sociol. 86:295-319

Wilson WJ. 1987. The Truly Disadvantaged: The Inner City, the Underclass, and Public Policy. Chicago: Univ. Chicago Press

Wong MG. 1986. Post-1965 Asian immigrants: where do they come from, where are they now, and where are they going? Ann. Am. Acad. Pol. Soc. Sci. 487:150-68

Wong MG, Hirschman C. 1983. The new Asian immigrants. In Culture, Ethnicity and Identity: Current Issues in Research, ed. W McCready, pp. 381-403. New York: Academic

Yamanaka K, McClelland K. 1994. Earning the model minority image: diverse strategies of economic adaptation by Asian American women. Ethnic Racial Stud. 17(1):79-113

Zhou M, Logan J. 1991. Returns on human capital in ethnic enclaves: New York City's Chinatown. Am. Sociol. Rev. 54:809-20 